\title{
The Problem of Old Debts: Jewish Moneylenders in Northern Castile

\author{
(Belorado and Miranda de Ebro, ca. 1300)
}

Maya Soifer Irish*

Rice University

El problema de las «entregas»: Prestamistas judíos en el Norte de Castilla (BeLORAdo y Miranda de Ebro hacia 1300). - Estudio de las relaciones económicas entre judíos y cristianos a comienzos del siglo XIV en el Norte de Castilla, especialmente en relación al préstamo de dinero efectuado por judíos. Tratándose de transacciones económicas entre individuos de distinta confesión religiosa, los interesados recurrían a los procedimientos establecidos en el derecho consuetudinario, y hacían uso de la negociación con el objetivo de resolver conflictos y generar el mayor consenso posible entre las distintas comunidades. A medida que los prestatarios cristianos iban incumpliendo la devolución de préstamos, tales negociaciones fracasaron debido a una combinación de factores internos y externos. En Belorado y en Miranda de Ebro, la colaboración de los oficiales reales en la colección de las deudas suscitó protestas de los concejos, que acusaban a los prestadores judíos de violar los privilegios locales y de empobrecer a los deudores. Las tensiones entre los cristianos y los judíos de estas villas fueron en aumento cuando los mecanismos de resolución de conflictos quedaron trastocados y la ejecución de los pagos de las deudas quedó sustraída al control local.

Palabras clave: Historia de los judíos; Castilla; deudas; poder real; concejos; resolución de conflictos; relaciones económicas interreligiosas.

Focusing especially on Jewish moneylending, the article explores economic relations between Jews and Christians in Northern Castile at the turn of the fourteenth century. During interfaith economic transactions, Jews and Christians followed the procedures established by customary law, and engaged in negotiations to resolve conflicts and generate inter-communal consensus. As more and more Christians defaulted on their loans, however, such negotiations often collapsed due to a combination of internal and external pressures. In Belorado and Miranda de Ebro, royal assistance with debt collections elicited

\footnotetext{
* maya.s.irish@rice.edu
} 
strong protests from town officials, who accused Jewish moneylenders of violating local privileges and impoverishing Christian debtors. Tensions developed between Jewish and Christian residents of these towns when the traditional mechanisms of conflict resolution were upended, and the enforcement of loan repayment was taken away from local control.

Keywords: Jewish History; Castile; Loans; Royal Power; Local Councils; Conflict Resolution; Interfaith Economic Relations.

Although some scholars have argued that routine interfaith social and economic interaction bred familiarity and even friendship, there is plentiful evidence that such contacts could cut both ways. 'This was certainly the case in medieval Northern Castile, where economic relations between Jews and Christians occasioned friendly exchanges, but were also often the cause of friction and discord. ${ }^{2}$ Whenever disagreements arose, inter-communal contacts, especially negotiation of agreements (official and informal), intended to anticipate or smooth over friction and conflicts, were crucial to stabilizing interfaith relations. In Northern Castile, these negotiations were a source of constant preoccupation for both Jews and Christians, especially in the latter part of the thirteenth century, when disputes over taxation, judicial autonomy, and especially moneylending increased in both frequency and intensity. One suspects that in most cases, the two communities were able to arrive at mutually acceptable terms. However, the Crown's assistance with debt collections, seen by the concejos as a violation of local privileges, upended the traditional mechanisms of conflict resolution and elicited a strong backlash against the Jews and their credit operations.

\footnotetext{
${ }^{1}$ Joseph Shatzmiller, Shylock Reconsidered: Jews, Moneylending, and Medieval Society (Berkeley: University of California Press, 1990), 123; Elka KLeIn, Jews, Christian Society, and Royal Power in Medieval Barcelona (Ann Arbor: University of Michigan Press, 2006), 162. However, see also David Nirenberg, Communities of Violence: Persecution of Minorities in the Middle Ages (Princeton: Princeton University Press, 1996), esp. pp. 30-40, and William C. Jordan, "Jews on Top: Women and the Availability of Consumption Loans in Northern France in the Mid-Thirteenth Century," Journal of Jewish Studies 29 (1978), 39-56.

${ }^{2}$ Teofilo Ruz, "Trading with the 'Other:' Economic Exchanges between Muslims, Jews, and Christians in Late Medieval Northern Castile," in eds. Roger Collins and Anthony Goodman, Medieval Spain: Culture, Conflict, and Coexistence; Studies in Honour of Angus MacKay (Palgrave Macmillan, 2002), 63-78: 76. On Jewish moneylending in the Crown of Aragon see Yom Tov Assis, Jewish Economy in the Medieval Crown of Aragon, 1213-1327 (Leiden: Brill, 1997).
} 
Since the royal chancery routinely handled appeals from Jewish and Christian communities and issued charters outlining the king's decisions, inter-communal contacts left behind the lengthiest documentary record. These documents show that interfaith property sales and loan agreements were rather elaborate affairs that brought together not only the parties directly involved in the transaction, but also witnesses from both religious communities, as was required by Castile's customary law. More intriguing and perhaps suggestive of the normalcy that characterized most interfaith encounters are records of transactions between Christians that list Jews among the witnesses, even though there is no apparent reason for their inclusion. For instance, a 1222 sale of a few properties by one Christian family to another, in Sahagún, was witnessed by Benaito, Iudeo, whose name appeared at the end of a long list of Christian witnesses, among them, several priests and chaplains. ${ }^{4}$ Similarly, in 1233, a group of artisans witnessed a sale of a house in the city of León. The group included a bridle-maker (frenarius), a girdler (corrigiarius), a shoemaker (zapatarius), a skinner (pellicier), a buckle-maker (fiblilero), and a scabbard-maker (vaginarius). Unlike the Christians, the two Jews who appeared among the witnesses Iaques, iudeus and Cide, iudeus- did not have their professions appended to their names, although they were probably also artisans. ${ }^{5}$ The two documents conjure a picture of cohesive neighborhoods, whose Christian and Jewish residents were on friendly enough terms with each other to come together as witnesses when called upon to do so by their neighbors.

Whenever an interfaith transaction was about to take place, a group of Jews and Christians appeared before a public notary or a scribe of the town council, and had the contract recorded and certified by a scribe, who

\footnotetext{
${ }^{3}$ On the established procedure for dealing with interfaith property sales in León $\left(11^{\text {th }}\right.$ and $12^{\text {th }}$ centuries), see Javier CASTAÑo, "Los documentos hebreos de León en su contexto prenotarial," in Elena Romero, ed., Judaísmo hispano: Estudios en memoria de José L. Lacave Riaño (Madrid: CSIC, 2002), vol. II, 459-481.

${ }^{4}$ Archivo Histórico Nacional [hereafter AHN], Clero, Sahagún, carp. 912, no. 8; Colección diplomática del monasterio de Sahagún (857-1500), vol. V (1200-1300), ed. José A. Fernández Flórez (León: Centro de Estudios e Investigación "San Isidoro," 1994), 138-139.

${ }^{5}$ Archivo de la Catedral de León [hereafter ACL], no. 6130; Colección documental del Archivo de la Catedral de León [hereafter CDACL], vol. VIII (1230-1268), ed. José M. Ruiz Asencio (León: Centro de Estudios e Investigación "San Isidoro," 1993), 24-25.
} 
affixed his signature below those of witnesses of both faiths. One such transaction took place in Astorga (León) in 1262, when Abrafan Pardal and his wife Ourodueña went to the town's public scribe with a group of Christians and Jews to record a property transaction that stemmed from a debt owed to them by Yuan (Juan) Marcos, a Christian. In lieu of the debt, Abrafan seized Juan's estate and pawned it to two Christian brothers, Juan and Miguel Rodríguez, for 22 maravedis, with a stipulation that Juan Marcos or his heirs retained the right to recover the estate. To make the agreement "more binding" (mais firme) Abrafan signed his name in Hebrew letters. The archdeacon of Astorga, a judge (alcalde), a knight (cavallero), a royal merino, as well as three Jews were among those who were present during the transaction and acted as witnesses. ${ }^{6}$

The presence of witnesses from both faiths not only satisfied a long-standing custom, but also "smoothed over" a conflict-prone situation, in which a Jewish moneylender's right to collect the debt was pinned against the insolvency of the Christian debtor, whose loss of an estate was likely to become permanent. This and other similar documents underscore the fact that communal cooperation and approval were essential for the success of interfaith transactions, especially those that involved the sensitive issue of Christians' debts to Jews. The importance of communal consent was amplified in the late thirteenth and early fourteenth century, as a growing number of Christians could not or would not meet their credit obligations to Jews. A proliferation (by Northern Castilian standards) of records during this period documenting Christians' inability to pay their debts to Jews and the loss of land or other property that stemmed from their insolvency indicates a problem that quickly transcended interpersonal relations, becoming a communal issue.

It goes without saying that most debts contracted by Christians with Jews were small consumption loans that were repaid quickly and left few traces in the documentation. ${ }^{7}$ Even in cases when debts could not be collected on time, it made good business sense for the Jews

\footnotetext{
${ }^{6}$ Colección documental del Archivo Diocesano de Astorga, ed. Gregoria CAVERo Domínguez et al. (León: Centro de Estudios e Investigación "San Isidoro," 2001), 121122; Justiniano Rodríguez Fernández, Las juderías de la provincia de León (León: Centro de Estudios e Investigación "San Isidoro," 1976), 357.

${ }^{7}$ William C. Jordan, "Women and Credit in the Middle Ages: Problems and Directions," The Journal of European Economic History 17 (1988), 33-63: 37, 57.
} 
to renegotiate payment deadlines instead of antagonizing clients by having the entregadores take them to court and seize their property. Popular hostility was also an important factor to consider, as some clients were unscrupulous and powerful enough to defy the royal protection of the Jews and attack them over a business deal gone awry. Nevertheless, conflicts could and did arise over the issue of unpaid debts. Given the delicacy of the situation in which Jewish creditors found themselves if they chose to take the matter to court, communal legislation regulating such cases was of immense importance in helping diffuse potential tensions. The Libro de los Fueros contained several articles that addressed the problem of contested loans. One fuero stipulated that if a Christian debtor denied the validity of the contract presented by his Jewish creditor, an inquiry was to be conducted by the alcalde (judge): if the contract was found to be valid, the debtor was fined 60 sueldos on top of repaying the loan; otherwise, the Jewish creditor lost the loan and had to pay the same amount in fines. ${ }^{10}$

${ }^{8}$ Porteros and entregadores were royal agents entrusted with collections of outstanding debts to Jewish moneylenders. A late fourteenth-century document indicates that porteros and entregadores had different functions: the former ratified letters of obligation, while the latter carried out the confiscations of property. See Francisco Ruz GómEz, "Aljamas y concejos en el Reino de Castilla durante la Edad Media," Espacio, Tiempo y Forma. Historia Medieval 6 (1993), 57-78: 66. In the documents that I examined, however, there seems to be no clear distinction between the two types of officials. See also Mark Meyerson, Jews in the Iberian Frontier Kingdom: Society, Economy, and Politics in Morvedre, 1248-1392 (Leiden: Brill, 2004), 200; Nina Melechen, "Loans, Land, and Jewish-Christian Relations in the Archdiocese of Toledo," in ed. Larry Simon, Iberia and the Mediterranean World of the Middle Ages (Leiden: Brill, 1995), vol. I, 185-215: 205.

${ }^{9}$ Consider, for example, the episode that transpired in Abelgas [de Luna], in midthirteenth century (precise date is unknown). The canons of Santa María de Abelgas complained that the son of Domingo García de Luna had imprisoned several Jews and swore to hold them until they paid him a ransom, saying he cared nothing for the royal authority ("Filio Dominico García de Luna tenía elos iudeos presos e díxoles Iohannes Castellano ke los soltás, ke pesaría al re e a don Gundisaluo, e ille respón ke non daría por lo re nada e non dimisit eos donec pectauerunt de suos denarios"). ACL no. 598 (CDACL VIII, 172-173).

${ }^{10}$ Libro de los fueros de Castiella, ed. Galo SÁNchEZ (Barcelona: Ediciones El Albir, 1981), tit. 61 ("Esto es por fuero: que sy judio demanda a cristiano deuda por carta et dise el cristiano que non le a de dar nada, deue el alcalle tomar la carta, et deue sacar los pesquiridores. Et sy el judio pudier prouar, deuel dar la deuda el cristiano; et peche sesenta sueldos. Et sy judio non prouar la carta, deue perder la deuda e pechar sesenta sueldos"), 34 . 
Another fuero stated that a Christian with a "manifest" unpaid debt to a Jew could be seized and physically held until the loan was repaid."

Of course such communal legislation could do little to dispel resentment of a Christian debtor who lost freedom or property over an unpaid debt to a Jew. It did, however, give a measure of legitimacy to the idea that loans contracted with Jewish moneylenders had to be repaid, and even provided a mechanism -effective or not is another matter- for collecting old debts to Jews. However, communal consent was essentially rendered irrelevant when the enforcement of loan repayment was taken away from local control and placed in the hands of outsiders -royal bureaucrats. The Libro de los Fueros reflected Old Castile's customary law as it existed in the first half of the thirteenth century. When Alfonso $X$ attempted to replace local fueros with a unifying code of law -the Fuero real- the issue of local control over old debt collections was left unaddressed. It appears that the king had made a surreptitious decision that henceforward the royal entregadores would be entrusted with this function, bypassing officials of the concejos. Facing protests from the urban procurators at the 1293 Cortes in Valladolid, Sancho IV half-heartedly reassured them that local alcaldes would still be in charge of collecting old debts to Jews, except, the sly king added, in places where the royal merino was already collecting them. ${ }^{12}$ What Sancho "forgot" to mention was the fact that the merino mayor was responsible for the entregas in the entire region of Old Castile. ${ }^{13}$

${ }^{11}$ Ibid., tit. 96 ("Esto es por fuero de todo omne que deua deuda manifiesta a judio o non auyere de quela pagar: quel prendan el cuerpo fasta que page al judio la deuda, asy commo fuero es; et non le saque dela villa"), 49.

${ }^{12}$ Cortes de los antiguos reinos de León y de Castilla (Madrid: Real Academia de la Historia, 1861), vol. I [hereafter Cortes I], 111: "Otrossi alo que nos dixieron en razon delas entregas delas debdas delos iudios, que dizen que fazen los porteros delos iudios en las nuestras villas e en los nuestros logares, lo que dizen que non fue en tienpo del Rey don Ferrando nuestro auuelo nin del Rey nuestro padre, etque nos pidian merçed quelas entregas quelas fagan por mandado delos alcaldes assi commo solian seer en tienpo delos otros rreyes que fueron ante que nos; a esto tenemos por bien que en los logares do el nuestro merino mayor deue fazer las entregas delos iudios quelas faga, et en los otros logares quelas fagan por mandado delos alcaldes, assi como se solian fazer en tienpo del Rey don Fferrando nuestro auuelo e del Rey don Alfonso nuestro padre."

${ }^{13}$ According to the Accounts Book of 1290-1292. See Francisco HernándeZ, Las 
One imagines that the town representatives were none too pleased with the king's answer. Not only were the moneylenders in question members of a minority group, whose religious beliefs, supposed wealth, and privileged position with the Crown all rendered them suspect in the eyes of Christian townsmen, but also entregadores impinged on local privileges at a time when Castilian communities faced multiple economic and political pressures. Unlike local judges, royal collectors of debts to Jews were not likely to be sympathetic to the plight of the lessfortunate debtors who had fallen behind on their payments and faced losing land or other property as a consequence of the entregas.

The controversy over the collection of old debts therefore struck at the heart of several critically important issues. Not only was the economic livelihood of both communities at stake in the conflict, but also it set the rights and privileges of the aljamas on the collision course with those of the concejos. In the negotiations that ensued, the Crown usually played the role of an arbitrator at the later stages, but the initial bargaining occurred at the local level during face-to-face meetings between representatives of Jewish and Christian communities. By a lucky chance, records of such negotiations have survived to permit a detailed examination of how they were conducted, what goals were pursued by either side, and what impact these local controversies may have had on the state of Jewish-Christian relations in Northern Castile. The records hail from two small towns in the Burgos region -Belorado and Miranda de Ebro.

Both Belorado and Miranda de Ebro had well-established Jewish communities that traced their origins to at least the early twelfth century. ${ }^{14}$ A royal town only about 30 miles east of Burgos, Belorado neverthe-

rentas del rey: sociedad y fisco en el reino castellano del siglo XIII. Estudio y documentos (Madrid: Fundación Ramón Areces, 1993), vol. I, cxxxviii, 135-137.

${ }^{14}$ Several studies are dedicated to the Jews of Belorado and of Miranda de Ebro. See Fidel Fita, "La aljama hebrea de Belorado. Documentos históricos," Boletín de la Real Academia de la Historia 29 (1896), 338-345; Luciano Huidobro and Francisco CANTERA, "Juderías burgalesas (Beleña, Belorado)," Sefarad 13 (1953), 35-59; Inocencio Cadiñanos Bardecí, "Los judíos de Belorado y sus contornos," Sefarad 54 (1994), 227-251; Francisco Cantera, "De Hispania Judaica. La judería de Miranda de Ebro," Sefarad 1 (1941), 89-140, and Sefarad 2 (1942), 325-375; Inocencio CADIÑANOS BARDECÍ, "Precisiones sobre la sinagoga de Miranda de Ebro," Sefarad 54 (1994), 41-45. 
less was not part of the Burgalese señorio, and remained independent despite being ruled by a succession of royal servitors. ${ }^{15}$ At the end of the thirteenth century, Miranda was part of the diocese of Calahorra, but was later given by the king to the bishop of Burgos, before passing, in the late 1360s, under the control of the Burgalese concejo. ${ }^{16}$ Of the two Jewish communities, the aljama of Belorado was clearly the more affluent one, with a tribute of 8,500 maravedís to Miranda's 3,312 maravedís, according to the 1290 Partition of Huete. The prosperity of the Jews of Belorado stemmed, in part, from the involvement of its members in moneylending, and in part from its strategic location on the Camino de Santiago, in a town with a major market that attracted traders from towns and villages miles away. Several important Jewish tax collectors and financiers came from Belorado; among them, Samuel of Belorado, who was regularly mentioned in the royal Books of Accounts as a collector of royal tribute. ${ }^{1}$

Yet, the affluence of the Belorado's Jews did not provide an adequate safeguard against the financial squeeze affecting aljamas throughout Northern Castile. Like the Jewish moneylenders elsewhere, the town's Jewish creditors were forced to pursue debt collections more aggressively, provoking an outcry from the Christian community. The first documented sign of tensions came in 1301, when the concejo of Belorado obtained a privilege from Fernando IV that required the aljama to be responsible for the maintenance of the royal castle's tower of Homenaje ('Keep') thus considerably increasing the Jewish community's tax burden. Even more tellingly, the Jews of Belorado and its surroundings were banned from entering the town on market day (Monday) and making purchases there. ${ }^{18}$ In attacking the Jews' economic livelihood, the concejo was likely responding to the Jews' redoubled efforts at collecting debts from the disaffected

${ }^{15}$ Don Lope Díaz de Haro in the $13^{\text {th }}$ century, and Don Sancho, brother of Enrique II, in the latter part of the $14^{\text {th }}$ century, see CADIÑANOs BARDECí, "Los judíos de Belorado," $231,233$.

${ }^{16}$ Juan Antonio Bonachía, El señorío de Burgos durante la Baja Edad Media (12551508) (Valladolid: Universidad de Valladolid, 1988), 34.

${ }^{17}$ Fritz BaER, Die Juden im Christlichen Spanien. I. Urkunden und Regesten. 2: Kastilien/Inquisitionsakten (Berlin: Im Schocken Verlag, 1936), 90-91.

${ }^{18}$ Biblioteca de la Real Academia de la Historia (hereafter RAH), MS. 66.981. O-16, ff. 403v-404; HuidoBro and CANTERA, "Juderías burgalesas," 52-53. 
Christians, who accused the Jews of being driven by greed and resented the wealth built, they thought, on the backs of Christian debtors. ${ }^{19}$

Fernando IV's concession to the concejo could not resolve the simmering tensions over the issue of outstanding loans. Only one year later, in 1302, the concejo and the aljama began negotiations to address the problem more directly. In March of that year, representatives of both communities gathered in the presence of Garçi Ferrandez de Villamayor, Castile's adelantado mayor ('royal governor'), and after many deliberations drafted an agreement, which was then signed by about two dozen Jewish and Christian witnesses. ${ }^{20}$ The agreement reveals a great deal about the conflict-prone nature of the Jews' credit operations in small-town Castile. Behind the formalized language of the accord, one detects two communities at loggerheads over their conflicting objectives, as the Jews' determination to collect their debts as promptly as possible was matched by the Christians' equally strong determination to delay the payments for as long as possible. ${ }^{21}$ According to the text of the agreement, Jewish creditors had complained that Christian debtors were trying to extend their payment deadlines by offering the Jews señales, best translated as 'earnest money'. ${ }^{22}$ In all likelihood, señales were small payments

\footnotetext{
${ }^{19}$ This was an ongoing theme in the complaints presented against the Jews at the Cortes.

${ }^{20}$ Two versions of this agreement survive, both preserved at the RAH, in sixteenthcentury copies (MS. 66.977. O-16, ff. 400v-401v, and MS. 66.974. O-16, ff. 399v-400r). The shorter version appears to be a derivative of the longer version, despite having a different date (March 3, instead of March 13 of the longer version), and different Jewish witnesses. The longer version is also found at the Belorado Municipal Archive, and was published by Huidobro and CANTERA, "Juderías burgalesas," 44-46, and by CADIÑANOS BARDECI, "Los judíos de Belorado," 244-246.

${ }^{21}$ A similar situation existed in the lands of the Crown of Aragon, where Jewish moneylenders also encountered grave difficulties with collecting outstanding debts. See Assis, Jewish Economy, 39.

${ }^{22}$ See Title V, Law VII of the Fifth Partida (Las Siete Partidas): "Señal dan los homes unos a otros en las compras, et acaesce que se repiente despues alguno dellos [...] etc." Samuel Parsons Scott translates "señal" as 'earnest money', and adds in a footnote that "the arrha, or earnest money of the Romans, was merely a penalty imposed for nonperformance of the contract of sale by the purchaser." Las Siete Partidas. Vol. IV: Family, Commerce, and the Sea, ed. Robert I. Burns (Philadelphia: University of Pennsylvania Press, 2001), 1029. Prof. William C. Jordan suggested the alternative definition, more
} 
intended to buy debtors more time to settle their obligations, while preventing creditors from seizing their property. If the Jews chose to accept señales, year after year, they faced the danger of never getting the full amount due to them, since the Cortes legislation only allowed them six years to collect debts. On the other hand, the pressure must have been considerable for the Jews to accept señales, because a refusal to do so carried the risk of antagonizing their Christian clients. Confronted with this no-win situation, the Jews of Belorado presented their case to the concejo, who accepted their reasoning and agreed that henceforward the payment of debts could not be delayed on account of señales (que las debdas de los judios non se demoren por señales).

The concejo did not make this concession simply out of the goodness of their hearts. In return, the town council received complete control over collection of debts. Making no mention of royal entregadores, the agreement gave the officials of the concejo the power to assist the Jews at every stage of the entregas. If a Jew or a Jewess wanted to demand a debt from a resident of Belorado, he or she had to present their letter of obligation to a judge or a merino of Belorado, who would appoint a council to look into the matter. Its representatives would then go to the house of the debtor or the guarantor and seize the property in the amount of the debt indicated in the letter of obligation. The debtor had three days to either pay off the debt or to increase the value of the surety, after which period the officials sold the debtor's movable property in nine days, and real estate in thirty days. It was the officials' task to ensure that a Jew or a Jewess collected their debts "without any delay." If help was needed in enforcing this agreement, the judges (alcaldes), members of the town councils, and the prestamero ('priest-in-training') were to go with the Jews and ascertain that the debts were paid to them in full (conplidamiente). ${ }^{23}$

Was the agreement enforced, and if so, did it help ease tensions between the two communities of Belorado? Only circumstantial evidence exists and it points toward negative answers to both questions. The royal control and interference in the economic and political fortunes of Belorado

appropriate for the context of the Belorado agreement.

${ }^{23} \mathrm{RAH}$, MS. 66.974. O-16, ff. 399v-400r; Huidobro and CANTERA, "Juderías burgalesas," 44-45; CADIÑANos BARDECí, "Los judíos de Belorado,” 244-245. 
was too pervasive to allow for communal agreements to make a difference. In the several years following the 1302 agreement, Fernando IV's chancery issued several letters that could potentially upset the delicate balance of inter-communal relations in the town. First, at the end of 1303, the king responded to the town council's petition to appoint a scribe, conceding the privilege on the condition that the scribe records the debts (deudas) the Jews owed him. Belorado's aljama must have been in arrears on the payment of pechos to the king, which in itself is an indirect testimony to their continued difficulties in collecting unpaid debts from Christians. ${ }^{24}$ The subject of Jewish pechos from Belorado elicited the chancery's interest at least twice during these years. In 1303, Fernando allowed the concejo to collect the tax from the Jewish community, in order to compensate the town for the loan it had given the king to repair the walls of Zamora. But only two years later, in 1305, the king issued an unequivocal demand that the town's Jews were to pay their pechos separately from the Christians by dividing the taxes equitably among themselves, and bringing the money to town in order to give it directly to the royal officials. ${ }^{25}$

Given the Crown's concerns over the timely payment of pechos by the aljama of Belorado, it is not unreasonable to suppose that the king, possibly after receiving a plea from the town's Jews, chose to rely on the services of entregadores to collect debts from Christians, ignoring the communal agreement of 1302. If that was indeed the case, then the privilege given to the town at the 1325 Cortes in Valladolid by the young Alfonso XI was in step with the Crown's decision to exert greater control over the Jewish finances in Belorado. The privilege stated that the Jews would be given a separate judge to decide their cases. The description of the privilege is too laconic to determine whether the judge in question was appointed to hear cases between Jews and Christians. Since by all appearances that was indeed his task, the royal order was in direct violation of the 1302 agreement, which had assigned this function to the alcaldes of the concejo. The privilege also reveals further evidence of inter-communal friction in Belorado. The Jews were once again forbidden to trade with Christians at the Monday market, because of their propensity for

\footnotetext{
${ }^{24}$ RAH, MS. 66.976. O-16, f. 400; Huidobro and CANTERA, "Juderías burgalesas," 54.

${ }^{25}$ Huidobro and CANTERA, "Juderías burgalesas," 54-55.
} 
"fraud" and "roguery" (fraudes y bellaquerias). ${ }^{26}$ The prohibition was reiterated in $1333 .^{27}$

Therefore it seems likely that the inter-communal negotiations of 1302 failed to normalize the state of Jewish-Christian relations in Belorado. The agreement's existence shows that had they been left to their own devices, the two communities could find common ground and perhaps even resolve their differences to mutual satisfaction. However, the pull of the triangular relationship between the Jews, the concejos, and the Crown was as strong in Belorado as it was in the rest of Northern Castile, and it bent local interfaith relations out of shape by harnessing the Jews' credit operations among Christians to the financial needs of the Crown.

An even more vivid example of the powerful influence exerted by the monarchy over local politics comes from the town of Miranda de Ebro. A series of documents preserved in the town's municipal archive and published over seventy years ago by Francisco Cantera show a richness of detail rarely found in Northern Castile and allow one to follow the many twists and turns of the drama that unfolded in this northeastern corner of the kingdom beginning in the last years of the thirteenth century. ${ }^{28}$ The drama spanned several decades and involved many protagonists with conflicting interests and agendas. On the one side, there were Jewish creditors from Miranda, Haro, and Pancorbo whose livelihood and ability to meet their tax obligations to the Crown depended on collecting debts in a timely manner from the inhabitants of Miranda. Their efforts were countered by Christian debtors who hid letters of obligation in order to evade payments, and by the concejo of Miranda that tried to protect its vecinos from creditors by evoking the town's immunity from the intru-

${ }^{26}$ RAH, MS. 66.972. O-16, ff. 398r-399r; Huidobro and Cantera, "Juderías burgalesas," 55-56.

${ }^{27}$ RAH, MS. 66.997. O-16, ff. 408v-409r; Huidobro and CANTERA, "Juderías burgalesas," 56.

${ }^{28}$ As of 2009, the documents were still housed at the municipal archive of Miranda de Ebro. Francisco Cantera's transcripts and the commentary were published, in two installments, in the two inaugural issues of Sefarad. See Francisco CANTERA, "De Hispania Judaica. La judería de Miranda de Ebro (1099-1350)," Sefarad 1 (1941), 89-140, and "La judería de Miranda de Ebro (1350-1492)," Sefarad 2 (1942), 325-373. 
sion of entregadores. The king played the role of a mediator, walking a thin line between the need to have the debts collected and deposited into royal treasury in the form of Jewish pechos, and the fear of antagonizing the concejo by trampling its privileges.

Strictly speaking, the drama was another case of negotiations between the local concejo and the Jewish aljama. However, the case exemplifies the process through which local tensions could feed into the kingdomwide malaise that began to affect Jewish-Christian relations in the early fourteenth century. On March 8, 1294, the alcalde ('judge') of Miranda, García Martínez, accompanied by two jurados ('local council representatives') and a number of omes buenos from Miranda and the environs, held a meeting at the graveyard of the church of Santa María with ten Jewish representatives. During the meeting, the Jews were asked if they had obtained "illegal letters" from the king that authorized the royal merino to appoint a portero in Miranda who would collect the debts owed by local Christians to Jews. The alcalde had raised this issue with Rabi Çaguy, Çaguy Pardo and other Jews before, in January of the same year, but now he wanted assurances from the Jewish creditors that they would no longer use letters that so blatantly violated the privileges listed in the town's fuero. The Jewish representatives categorically denied receiving such letters from the king or the merino, and promised never to obtain them in the future. Moreover, they declared themselves perfectly satisfied with the assistance provided by the concejo and the alcalde in the matter of collecting old debts (entregas). Their only complaint concerned the admissibility of testimony of two Christians against a Jew, which they considered unjust. The alcalde then responded that no injustice was being committed, since a testimony of two Jews against a Christian was valid, as well as that of two Christians against a Jew. He failed to persuade the Jewish representatives on this point, but they did sign a memorandum acknowledging their satisfaction with the concejo's management of the entregas. $^{29}$

${ }^{29}$ Archivo Municipal de Miranda de Ebro (hereafter AMME), L-H0213-053, CANTERA, "La judería de Miranda de Ebro (1099-1350)," 112-113. Ten Jews are mentioned in the Castilian text as being present at the meeting; eight of them are from Miranda: Sento [Shem Tov] the alfaquin ['physician'], his sons Çagui [Isaac] and Hamuy, Çagui (son of Ordoña), Hazibuena (widow of Barzilay), Alazar the alfayate ['tailor'], his brother Çagui, and Juçe; and two are from nearby towns: David de Haro and Mose de Pancorbo. Five of 


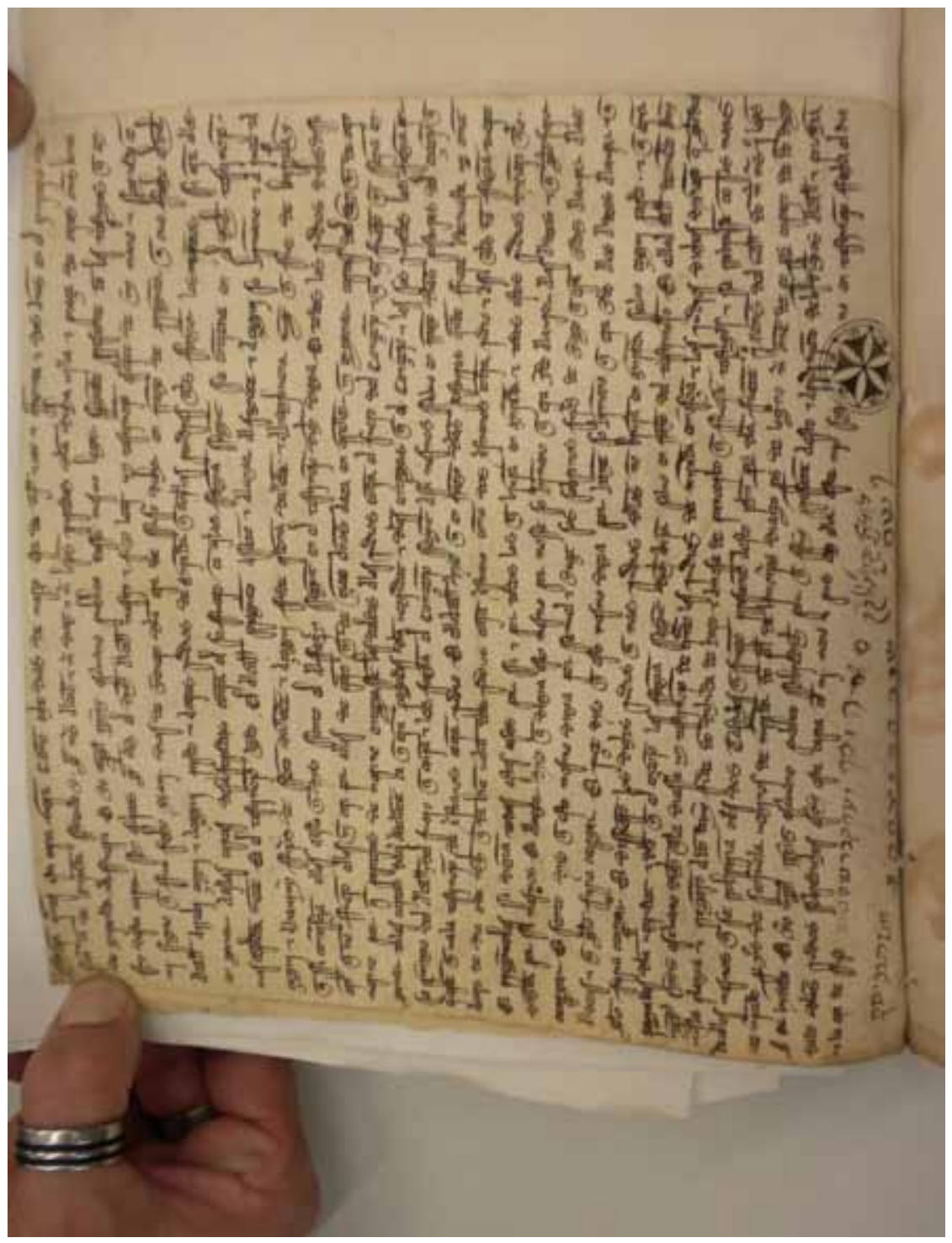

Fig. 1. Agreement on the Old Debts (entregas) between the municipal council of Miranda de Ebro and Jewish local representatives (1294, March 8). () Archivo Municipal de Miranda de Ebro, Libro H0213-053. 


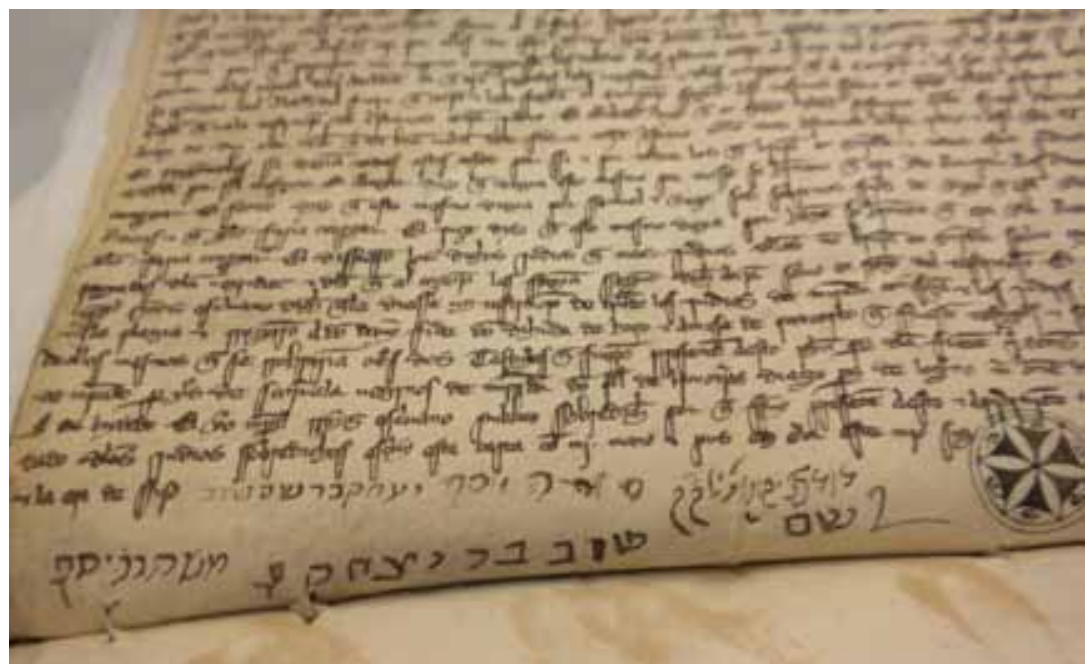

Fig. 2. Hebrew signatures affixed to the agreement on the Old Debts (1294, March 8). (c) Archivo Municipal de Miranda de Ebro, Libro H0213-053.

The presence during the meeting of two Jewish witnesses from the neighboring towns (David de Haro and Mose de Pancorbo) signaled that the matter of collecting old debts in Miranda concerned not only the town's Jews, but also a much wider network of Jewish creditors catering to Miranda's Christian vecinos. The sincerity of the concejo's commitment to facilitating the entregas was tested only two years later, when the tensions in Miranda exploded into a major controversy, involving several Jewish communities, an eminent royal servitor, and the Crown. The chronology of the events is difficult to reconstruct, but it appears that sometime in the summer of 1296, Diego López de Haro, lord of Vizcaya, who had recently entered the Castilian king's service, complained that he had not received a tribute from the Jews of Haro and the bishopric of Calahorra he was assigned as Fernando IV's servitor. ${ }^{30}$ In response, Polo

those present affixed their signatures, in Hebrew, at the end of the document (one of the

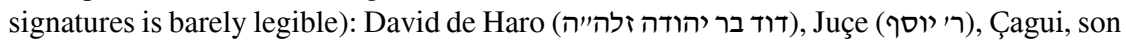
of Sento (יצחק בר שם טוב), Sento (שם טוב בר יצחק), and Mose de Pancorbo (משסה בר יוסף).

${ }^{30}$ According to the Partition of Huete (1290), many royal servitors were assigned tribute from specific Jewish communities. Among those receiving compensation from the aljama of Haro in 1290 were Infante Alfonso, the king's son, and Samuel de Belorado, 
Pérez, the royal tax collector in the bishoprics of Burgos and Calahorra, acknowledged that he was unable to collect tribute from the Jews of Haro. They had locked themselves up in their quarter and refused him entry, arguing that they could not pay until Christian debtors in the town of Miranda fulfilled their credit obligations. ${ }^{31}$ The royal chancery then dispatched an urgent letter to the alcalde and the concejo of Miranda, upbraiding them for disobeying the king's orders, and demanding immediate action. ${ }^{32}$

The letter alleged that the alcalde, the town council, and the public scribe of Miranda had done everything in their power to prevent the collection of debts owed to the Jews of Haro. This information came from two royal servitors, residents of Burgos, who had been sent to Miranda to conduct investigation. ${ }^{33}$ According to their version of the events, a Jew named Varon came to Miranda bearing letters of obligation that belonged to other Jews (most of them probably from Haro) and intending to plead cases with local Christians. Instead, he was seized together with the letters and held against his will on the orders of the alcalde. When the investigators went to see Diago Pérez, the town's public scribe, to get information on the debts owed to the Jews of Haro, the scribe flatly refused to show them the town's financial records. In fact, the investigators suspected that the scribe hid the loan contracts in conspiracy with two prominent men of Miranda, don Martín Martínez and don Yuanez de Vitoria, who owed the Jews a certain sum of money. The two men had promised to repay the debt after collecting the revenue from their landed

the royal tax collector, see HeRnÁNDEZ, Las rentas del rey, 153-154.

${ }^{31}$ Only six years prior to these events, in 1288 , the juderia of Haro was sacked by the troops of Sancho IV. According to the Partition of Huete, the king later forgave the Jews of Haro half of their tribute as a compensation for their losses, see HERNÁNDEZ, Las rentas del rey, 138.

${ }^{32}$ AMME, L-H0039-031. The long parchment contains the report of Polo Pérez, written down by his scribe, which includes the letter from the chancery of Fernando IV (dated August 11, 1296), and the copies of four loan contracts between Diago Martínez and Juzme of Haro (dated March-December 1294). Virtually no records of lending agreements between Jews and Christians in Northern Castile are extant, making this document exceedingly rare and valuable. The report itself is dated October 20, 1296. It was published by CANTERA, "La judería de Miranda de Ebro (1099-1350)," 118-123.

${ }^{33}$ The servitors' names are listed as don Esias and Garçia González [or Gutiérrez or Garcéz] of Burgos. 
estates, but now with the contracts safely put away they were denying ever borrowing money from the Jews. Moreover, the complaint went on, Fernant Martínez, son-in-law of Martín Martínez, and Johan Urtiz had promised to give the royal investigators 6,000 maravedís in entregas, but later denied ever making such a promise.

Upon receiving the investigators' report, the royal chancery's officials expressed surprise at the happenings in Miranda and the disservice done to the monarch by the town's prominent citizens. They ordered that the Jew Varon be released and handed over to the royal representatives together with the contracts, and that Fernant Martínez and Johan Urtiz pay the promised 6,000 maravedís in entregas. And while the citizens of Miranda were now held accountable for their debts, or at least a portion of them, the money did not go to the Jewish creditors. As soon as they obtained the records of old debts from the scribe, the investigators were to collect only the principal from every debt owed by men and women of Miranda, and then claim the money for the king. The chancery forgave the accumulated interest (tan bien del logro commo de la ganançia) and declared as invalid all the subsequent letters of obligation if the Jews were to present them.

In essence, the royal chancery's order in the summer of 1296 constituted a captio on a local scale: the Jews of Haro lost the interest portion of the loans, and the principle was confiscated in lieu of their outstanding taxes to the king. ${ }^{34}$ It may have been the first instance of direct royal interference with the Jews' outstanding loans in Northern Castile. Not until 1315 would the regents to Alfonso XI execute a kingdom-wide captio by canceling onethird of every debt owed to Jews and allowing the rest to be repaid in installments. ${ }^{35}$ The Jewish creditors from Haro likely suffered great financial loss as a result of this affair. This much is clear from the four surviving letters of obligation included in the report written by Polo Pérez (the tax collector). The letters document the loans taken by Diago Martínez, son of the archpriest, from don Juzme of Haro in 1294. The total amount of the four loans reached at least 368 maravedís, not counting the cost of the two fanegas of wheat Diago had borrowed from the Jew. Nevertheless, when Polo Pérez

${ }^{34}$ On captiones in France, see William C. JORDAN, The French Monarchy and the Jews: From Philip Augustus to the Last Capetians (Philadelphia: University of Pennsylvania Press, 1989), 9-31.

${ }^{35}$ Cortes I, 284. 
showed Diago the contracts and demanded payment, Diago claimed that he had never received from Juzme more than 332 1/2 maravedis in principal, and that the rest of the debt represented the built-in interest. Polo decided to take Diago's word for it (yo falle en uerdad que era assi), and accepted the 332 1/2 maravedis, citing the king's privilege canceling interest on all loans. ${ }^{36}$ There is no indication that Juzme or his representative was present during the transaction to challenge Diago's assertions.

The events of 1296 left a residue of frustration and resentment among Miranda's residents. True, Christians saw parts of their debts significantly reduced, but they still had to pay, losing the freedom to postpone payments for months or years on end. The concejo hated to see their decisions overridden by strangers - royal officials sent from Burgos. But the Jews lost the most from the affair. Not only did they suffer financial losses, but also they could no longer hope that the concejo would uphold the letter of the 1294 agreement and give them a helping hand in collecting outstanding loans. Now that the royal interference had dealt a fatal blow to the spirit of the 1294 agreement, debt collection in the town of Miranda became a particularly daunting task for the Jews, regardless of whether they came from Miranda or Haro. It is no wonder, then, that the Jewish creditors of Miranda, Haro, and Pancorbo banded together to try and get royal entregadores to perform this unpleasant duty for them. Sometime in late 1303 or early 1304, they sent representatives to Garçi Ferrandez de Villamayor, the adelantado mayor ('royal governor'), who were able to get an authorization to put a royal official, portero, in Miranda who would be responsible for collecting outstanding loans from the town's Christians.

It was this move by the Jews that precipitated a new chapter in the drama. Garçi Ferrandez sent his officials, merinos, to Miranda, who descended on the town and "took everything they could find" (les tomaron todo quanto les fallaren), thereby violating the town's privileges and fueros. This was the essence of the complaint the concejo of Miranda took to the royal court in the spring of $1304 .^{37}$ The council's representatives who appeared

${ }^{36}$ AMME, L-H0039-031. CAnTera, “La judería de Miranda de Ebro (1099-1350),” 122-123.

${ }^{37}$ AMME, L-H0190-022. The text has faded in the folds of the parchment, making it difficult to read in some places. See CAntera, "La judería de Miranda de Ebro (10991350)," 123-129. 
before the king were the town's alcalde, Garçi Martínez, as well as Diago Pérez and Ferrant Martínez -probably the same individuals who were involved in the 1296 events. The Jews sent their own representative, Haui [sic] Moreno, who was joined by two guarantors -Rabi Çahagui (Çagui) and Çahagui Pardo. Ten years previously, these two Jews of Miranda participated in negotiating the agreement with the concejo. The old spirit of cooperation was now all but dead, as the opponents faced each other over the divide of broken promises and unfulfilled obligations, made only wider by the official setting of the royal court. Haui Moreno brought letters of representation (personeria) from four Jews of Haro, one Jew of Pancorbo, and fifteen Jews of Miranda (among them, five women). ${ }^{38}$

When it was Haui Moreno's turn to answer the concejo's complaint, his words contradicted the Jews' claim, made during the meeting at Miranda's cemetery in 1294, that they had never received privileges from the king authorizing them to have a portero in the town. Alfonso $\mathrm{X}$ was the first monarch to grant such letters to the Jews of Miranda, and the charters were later confirmed by Sancho IV and the current monarch, Fernando IV. Haui brought the charters along to be examined by the king. It appears that the aljama had been denying their existence in the hopes of obtaining the town council's cooperation. Now that such hopes had dimmed, Haui dropped all pretenses and openly declared that the concejo was refusing to accept the validity of the Jews' privilege. In response, the representatives of the concejo vehemently objected to the Jews' petition to allow a portero administer the collection of outstanding loans in Miranda. They asserted that their town's privileges and fueros were much more ancient, having been first granted by Emperor Alfonso VI (emperador don Alfonso que la villa poblo), and confirmed by "other kings," and by king Fernando himself. These charters prohibited royal merinos from officiating in Miranda and its surroundings, and stated that only jurados appointed by the alcalde had the

${ }^{38}$ Haro: Yhuda, son of Juezme; Fazen [Juzme?], son of Santo; Daui, son of Rabi Çahat; Salamon son of Samuel. Pancorbo: Rab Don Esua. Miranda: Rabi Çahat [?], son of Hanini [or Hamui]; Yhuda, son of Çahagui de Suzana; Çahagui Pardo; Juze, son of Barzelay; Samuel his brother; Mosse, son of Juziel; Alazar his brother; Samuel, son of Çahagui; Daui son of Çagui; Juezme son of Çagui; Sol Uellida, daughter of Barzelay; Oro wife of Çidiello; Dona Venda, wife of [?]; Sol Uellida, wife of Mosse; Lunbre, wife of Santo. Some names have faded beyond recognition. AMME, L-H0190-022, see CANTERA, "La judería de Miranda de Ebro (1099-1350)," 124-125. 
authority to collect old debts in the town. ${ }^{39}$ They demanded that the Jews' privileges be destroyed (ronper) and that the concejo be compensated for damages stemming from the violation of the town's fuero.

Two opposing sets of privileges lay in front of the royal officials entrusted with resolving the suit, a vivid testimony to the duplicitous royal policy. Publicly, the monarchy had been reiterating its support for local officials doing the entregas, and prohibiting the use of special entregadores (at the Cortes of 1293, 1299, 1301). ${ }^{40}$ Away from the limelight, however, the Crown continued to encourage the employment of royal officials in collecting outstanding loans, and, it turns out, even granted some aljamas letters of privilege authorizing the placement of entregadores in their communities. Now the court had to pick sides and decide which side's privileges it was going to uphold. The outcome of the case was easy to predict. Fernando IV, a young king who had only recently come of age, needed all the support he could muster. Alienating the local council of Miranda was not a good option. Hence, the court declared that the Jews' letters of privileges violated the town's fuero and could not be carried out. Into the fire, therefore, the Jews' letters went. At the same time, the royal court made sure that the king got what was due to him, ordering that all the debts contracted since the reign of Fernando's father, Sancho IV, had to be collected by the alcalde of Miranda with no further delay ( sin otro alongamiento ninguno). ${ }^{41}$

The court's decision appears to have brought to an end the central chapter in the drama that drove a permanent wedge between the Jewish and the Christian communities of Miranda. Assuming the decision was indeed enforced, one can only speculate on how the Jews of Haro, Pancorbo, and Miranda managed to continue collecting outstanding loans from the residents of Miranda. It is fair to assume that they faced an uphill battle. It was a battle fought on daily basis not only by the three Jewish aljamas in this small northeastern corner of Castile, but also by Jewish creditors throughout the kingdom. On the Christian side, too, the issue of

\footnotetext{
${ }^{39}$ Christian representatives cited the fueros of Miranda and Logroño: "[...] segund que lo an de fuero et assi que lo ussauan en Logroño donde ellos an fuero."

${ }^{40}$ Cortes I, 111, 144, 149, 153.

${ }^{41}$ AMME, L-H0190-022, see CANTERA, "La judería de Miranda de Ebro (10991350)," 127-129.
} 
old debt collection continued to affect every community whose residents contracted loans with the "king's usurers." Disaffections born of local conflicts found their way to the halls where the urban procurators gathered for the meetings of the Cortes or ayuntamientos aired their grievances and compiled petitions they intended to present to the king. The Jews, too, came together occasionally to exchange opinions and draft collective plans for action. Not much is known about these inter-communal assemblies, but it is indisputable that they sent their own representatives to petition the king and try to counteract the influence of the Christian procurators. $^{42}$

Although the Jews of Haro had reasons to despair of ever obtaining a royal portero for Miranda, their spirits might have been raised by a royal privilege they, along with other Castilian aljamas, received from King Alfonso XI in August 1335. ${ }^{43}$ The privilege was a response to a petition composed at a Jewish assembly and delivered by its representatives to the royal court in Valladolid. ${ }^{44}$ The very first issue addressed by the petition was that of entregadores. The Jews complained that they had been driven to poverty and ruin (pobres e estragados) by the many obstacles that prevented them from collecting debts from Christians in a timely manner. The king responded by detailing the procedures the entregadores were to follow in collecting outstanding loans and by authorizing them to seize property in lieu of debts. He did not directly address the delicate issue of who would be responsible for appointing entregadores, but from the context it is clear that the king expected local alcaldes to be in charge of their operations and to impose a fine of 60 maravedis on debtors who

\footnotetext{
${ }^{42}$ Julio Valdeón BaruQue, Judíos y conversos en la Castilla medieval (Valladolid: Universidad de Valladolid, 2000), 36.

${ }^{43}$ AMME, L-H0190-008 (a 1363 copy of Alfonso XI's charter from 1335), see Cantera, "La judería de Miranda de Ebro (1099-1350)," 132-137.

44 "Sepades que los procuradores de las aljamas de los judíos de nuestros regnos nos vinieron a nos aquí a Valladolit, sobre fecho de las sus heredades que les nos mandamos agora entrar e nos mostraron en como son pobres e estragados por muchas daños e perdidas que an reçebido en sus faziendas, señaladamente en las sus deudas, non lo podiendo cobrar de aquellos que gelas deuen por muchos enbargos que ouieron, assy en razon de las esperas que nos mandamos dar a los christianos commo en las otras maneras de fuerças e de premias que les fueron fechas en los tiempos pasados," AMME, L-H0190-008.
} 
refused to pay off their loans. ${ }^{45}$ Only on private and ecclesiastical estates did Alfonso reserve the right to appoint entregadores if the local officials failed to do so. Four years later, at the Cortes of Madrid (1339), the king issued a decision that was less favorable to the concejos. It appeared to be a compromise that was unlikely to please either the town council or the Jews. Entregadores, the king stated, were to be appointed by the royal official, merino mayor of Castile, but they had to be Christian and come from among the local omes buenos. ${ }^{46}$

There is other evidence indicating that in the latter part of his reign Alfonso XI began to give his tacit approval to the royal officials' interference in the collection of outstanding loans. Once again, in 1347, the simmering conflict in Miranda drove the concejo's representatives to the royal court, where they complained bitterly about the supposed violation of their fuero by the merino mayor, who was presumably conducting his own entregas in the town. The omes buenos asked that the 1304 decision by Fernando IV's court be upheld. Alfonso obliged, imposing a fine of 600 maravedís on violators of his father's charter, but it is by no means clear how committed he was to enforcing his decision. ${ }^{47}$ The tensions between the Jewish and the Christian communities in Miranda showed no sign of abating, and a satisfactory resolution to the conflict was not anywhere in sight.

The drama had a sad and violent postscript. In 1360, during Enrique de Trastámara's invasion of Castile, Christian residents of Miranda took advantage of the anarchy to settle scores with the Jews by attacking the local judería. According to the Crónica del Rey don Pedro Primero written by Pero López de Ayala, after Enrique's troops had entered Castile through the Rioja and advanced toward Miranda, local residents took his

45 “ [...] el alcalle del lugar que lo constrenga e le ponga pena de sessenta maravedís que fasta plazo quieto faga la entrega [...]," AMME, L-H0190-008.

${ }^{46}$ Cortes I, 462.

${ }^{47}$ The privilege was confirmed by King Pedro on October 18, 1351. Pedro's letter contains copies of Fernando IV's original charter and of Alfonso XI's confirmation, dated November 10, 1347. The concejo of Miranda asked Pedro for a confirmation because Alfonso's letter "was written on paper and got torn" (esta dicha carta era escripta en papel e se ronpia), AMME, L-H0039-029. Enrique II confirmed it on February 5, 1367, AMME, L-H0190-021, see CANTERA, "La judería de Miranda de Ebro (1350-1492)," 341$343,350-351$. 
side and began to kill and despoil the Jews. ${ }^{48}$ King Pedro soon reclaimed the Rioja and punished those directly involved in the attacks on royal property during the invasion. Even so, two years later, in 1362, the royal merinos were still harassing residents of Miranda and confiscating their property in retaliation for killing their town's Jews. Pedro ordered all authorized seizures of persons and property to stop, and imposed a penalty of 600 maravedis. $^{49}$

All the while, Jewish creditors continued to do business among Miranda's Christians. Neither the seven-decade-long controversy over the status of entregadores, nor the civil war, not even the physical violence directed at local Jews could disrupt the painful process put in motion each time Jewish creditors loaned money to Christians, then waited, more often than not past the deadline, to collect their debts, and finally received a slow trickle of payments. For as long as the aljamas were connected by chains of financial obligations to the Crown, and the Christians needed consumption loans, the cycle that had proved so damaging to Jewish-Christian relations would persist. In 1367, representatives of Miranda's concejo visited Enrique II's court that happened to be passing through Haro, bringing letters that described the disastrous state of affairs in their town. Christian residents had borrowed "great quantities of money" (grandes quantias de maravedis) from the Jews, and now risked losing their property (perder lo que han) because of their inability to pay. Enrique granted the concejo an extension of two years on all loans contracted with the Jews, and waved all penalties and interest (non corran

48 "[...] E otro dia fué a Miranda de Ebro, por quanto avian robado alli á los Judios, é tenian la parte del Conde, é fizo y Justicia de omes de la villa." Crónica abreviada: "[...] E otro dia fué á Miranda de Ebro, por quanto avian robado é muerto alli los Judios, é tenian la parte del Conde, é fizo y justicia de dos omes de la villa, é al uno decian Pero Martinez, fijo del Chantre, é al otro Pero Sanchez de Bañuelos; é al Pero Marinez fizo cocer en un caldero, é al Pero Sanchez fizo asar estando el Rey delante, e fizo matar otros de la villa [...]," see Cayetano Rosell (ed.), Crónicas de los reyes de Castilla (Madrid: Ediciones Atlas, 1953), vol. I, 504; Pero LóPEZ DE Ayala, Crónicas, ed. José-Luis Martín (Barcelona: Planeta, 1991), 240-241. Julio VAldeón BARUQue, Los judios de Castilla y la revolución Trastámara (Valladolid: Universidad de Valladolid, 1968), 34.

${ }^{49}$ Pedro's letter is dated May 2, 1362, AMME, L-H0039-040, see CANTERA, "La judería de Miranda de Ebro (1350-1492)," 330, 348. 
penas [... nin logros) accumulated during that time. ${ }^{50}$ There is no way to gauge the effect of this order on the economic wellbeing of local aljamas, but chances are, Jewish creditors were soon back in Miranda, trying to solicit new loans and seek compensation on the existing ones. They had no choice: their livelihood, their reputation with the Crown, their very right to remain on the Castilian soil depended on it.

To conclude, negotiations between religious communities were an essential if often overlooked component of the Northern Castilian coexistence. Jews and Christians made efforts to generate inter-communal consensus on controversial issues, such as the collection of outstanding loans. Unfortunately, negotiations often collapsed due to a combination of internal and external pressures. The breakdown in local relations had serious implications. What began as relatively benign negotiations over local issues paved the way for renegotiation of the Jews' very position in relation to the kingdom's Christian community.

Recibido: $19 / 09 / 2014$

Aceptado: 20/11/2014

${ }^{50}$ Pedro added a caveat that the order did not apply to debts that affected royal "rentas e pechos e derechos." The letter is dated January 3, 1367, AMME, L-H0039-037, see CAntera, "La judería de Miranda de Ebro (1350-1492)," 349-350. 